\title{
PERANCANGAN SISTEM WAREHOUSE BANTUAN LOGISTIK KORBAN BENCANA ALAM, STUDI KASUS : GUNUNG MERAPI
}

\author{
Agus Purbayu, S.Si, M.Kom \\ Fakultas MIPA, Program Studi D3 Teknik Informatika \\ Universitas Negeri Sebelas Maret \\ Email: bayoe@mipa.uns.ac.id \\ Yuliana Agustiningsih, Amd \\ Fakultas MIPA, Program Studi D3 Teknik Informatika \\ Universitas Negeri Sebelas Maret
}

\begin{abstract}
ABSTRAK
Indonesia terletak pada pertemuan lempeng tektonik aktif, jalur pegunungan aktif, dan kawasan beriklim tropik, sehingga menjadikan sebagian wilayahnya rawan terhadap bencana alam. Jumlah korban bencana tergolong sangat tinggi dibandingkan dengan negara-negara lain. Selama ini prosespendistribusian bantuan logistik dari pemerintah seringkali kurang merata, danpersebaran posko seringkali menumpuk pada titik tertentu, sedangkan masih banyak korban yang tidak mendapatkan bantuan logistik. Penyebab kurang meratanya bantuan antara lain kurang meratanya informasi lokasi korban atauposko pengungsian dan tidak diketahuinya kebutuhan bahan bantuan logistik pada setiap posko pengungsi.

Dalam perancangan sistem dilakukan dengan menggunakan beberapa metode diantaranya analisa kebutuhan sistem, desain, coding dan testing. Pengumpulan data dilakukan untuk melakukan analisa kebutuhan system warehouse bantuan logistik. Metode yang digunakan dalam pengumpulan data adalah dengan melakukan wawancara dan studi pustaka. Tahap desain berupa perancangan user interface perangkat lunak yang dapat diperkirakan sebelum dibuat coding.
\end{abstract}

Hasil rancangan berupa sebuah sistem warehouse bantuan logistik bencana alam yang dapat menangani proses transaksi penerimaan, pengiriman dan permintaan barang. Dalam rancangannya aplikasi juga dapat mengelola data barang maupun anggota yang terlibat di dalamnya.

Kata Kunci : Bencana Alam, Sistem Warehouse, Bantuan Logistik,

\begin{abstract}
Indonesia is situated at the confluence of the active tectonic plates, the mountains, and the climate is tropical, so make the most of its territory vulnerable to natural disasters. The number of disaster victims belong to very high compared to other countries. During this process of distribution logistical support from the Government is often less evenly, and the spread of the post often accumulate at some point, while there are still many victims don't get logistical support. Causes less equality the help of, among others, less equality the location information of the victim or the evacuation command post and causing material needs logistical support at each refugee command post.
\end{abstract}

In the design of the system is carried out using several methods including needs analysis, system design, coding and testing. Data collection was done to perform needs analysis system of warehouse logistics assistance. Methods used in the collection of data is to conduct interviews and literature study. The design phase in the form of the design of the user interface of the software can be estimated before it made coding. 
The results in the form of a system of warehouse logistics assistance to natural disasters which can handle transaction processing, delivery and acceptance of the demand for goods. The Design of application include manage data items as well as members who are involved in it.

Keywords: Natural Disaster, Warehouse System, Logistical Support.

\section{PENDAHULUAN}

Indonesia merupakan negara kepulauan yang memiliki keadaan alam sangat beragam. Indonesia terletak pada pertemuan 3 lempeng tektonik aktif (lempeng indo-australia, lempeng eurasia, dan lempeng pasifik), jalur pegunungan aktif, dan kawasan beriklim tropik yang menyebabkan sebagian wilayah Indonesia sangat rentan terhadap berbagai bencana alam. Bencana alam yang pernah terjadi adalah meletusnya gunung merapi di Yogyakarta pada bulan oktober November tahun 2010. Peristiwa itu mengakibatkan ratusan ribu orang yang tinggal di sekitar lereng gunung merapi (Penduduk di Kabupaten Sleman Provinsi Yogyakarta, Kabupaten Magelang, kabupaten Klaten dan kabupaten Boyolali provinsi Jawa Tengah) tinggal di posko pengungsian.

Selama ini, penyaluran bantuan logistik masih menggunakan cara manual. Posko pengungsi harus menghubungi posko batuan via telepon ataupun sms untuk mendapatkan bantuan logistik. Pendataan stok bantuan di posko bantuan juga hanya sebatas catatan pada buku. Sehingga petugas posko bantuan harus menghitung dan melakukan pendataan sendiri terhadap bantuan yang diterima maupun dikirim. Hal ini tentu kurang efektif dan membutuhkan waktu yang lama. Sehingga masalah yang muncul adalah bantuan yang ada belum dapat tersalurkan dengan tepat. Persebaran posko seringkali menumpuk pada titik tertentu, sedangkan masih banyak korban yang tidak mendapatkan bantuan logistik. Penyebab kurang meratanya bantuan antara lain kurang meratanya informasi lokasi korban atau posko pengungsian dan tidak diketahuinya kebutuhan bahan bantuan logistik pada setiap posko pengungsi, sehingga mengakibatkan terjadinya penumpukan bantuan pada posko-posko tertentu.

Teknologi informasi dan meningkatnya jumlah pengguna internet menyebabkan perusahaan teknologi informasi mulai beralih menuju aplikasi. Perpindahan ini difaktori oleh keuntungan aplikasi itu sendiri, diantaranya mudah diakses menggunakan aplikasi browser, tidak perlu instalasi yang rumit, tingkat keamanan tinggi dan cepat dalam memproses data.

Berdasarkan uraian di atas, penulis tertarik untuk merancang sebuah sistem pengelolaan data penyaluran bantuan logistik yang diwujudkan dalam bentuk judul yaitu "Perancangan Sistem Warehouse Bantuan Logistik Korban Bencana Alam (Studi Kasus : Gunung Merapi)". Perancangan sistem warehouse dalam suatu posko bantuan akan merancang sistem yang mempermudah petugas dalam melakukan proses transaksi penerimaan dan pengiriman bantuan. Selain itu, dengan adanya sistem yang menangani warehouse posko bantuan, petugas akan mudah untuk melakukan stock opname yakni pengecekan berkala antara bantuan di gudang dan data di dalam sistem.

\section{METODOLOGI PENELITIAN}

\subsection{Pengumpulan Data}

Metodelogi Pengumpulan data yang akan digunakan dalam pembuatan penelitan penulis adalah sebagai berikut :

\subsubsection{Wawancara}

Metode pengumpulan data dengan cara bertanya langsung kepada responden yang dilakukan secara sistematis dan berlandaskan kepada tujuan penelitian.

\subsubsection{Pustaka}


Studi pustaka adalah metode pengumpulan data dengan membaca buku atau literatur - literatur yang berhubungan dengan permasalahan yang dijadikan objek dalam penelitian.

\subsection{Analisa Sistem}

Hasil dari pengumpulan data kemudian diolah menjadi proses bisnis dan kebutuhan -kebutuhan sistem yang dibutuhkan

\subsection{Perancangan Sistem}

Hasil dari pemetaan kebutuhan sistem dan proses bisnis yang terjadi kemudian dibangun rancangan sistem yang siap untuk digunakan membuat sistem

\section{HASIL DAN PEMBAHASAN}

\subsection{Landasan Teori}

Landasan teori yang digunakan dalam penelitian ini adalah sebagai berikut

\subsubsection{Warehouse}

Warehouse merupakan bagian dari sistem logistik perusahaan sebagai tempat penyimpanan barang (bahan mentah, parts, barang setengah jadi, barang jadi) pada dan diantara tempat asal dan tempat tujuan serta memberikan informasi kepada manajemen tentang status, kondisi, dan disposisi barang-barang yang sedang disimpan [6]. Gudang dibutuhkan dalam proses koordinasi penyaluran barang, yang muncul sebagai akibat kurang seimbangnya proses penawaran dan permintaan. Kurang seimbangnya antara proses penawaran dan permintaan mendorong munculnya inventory (persediaan). Persediaan membutuhkan ruang sebagai tempat penyimpanan sementara yang disebut sebagai gudang [6].

\subsubsection{Logistik}

Pengertian Logistik Menurut Para Ahli :

a. Logistik : Pekerjaan yang diperlukan untuk memindahkan material serta posisi inventory melalui Rantai Pasok [2]

b. Logistik : Proses perencanaan, pelaksanaan, pengontrolan, aliran biaya yang efektif, penempatan raw material, proses inventory, barang jadi serta informasi yang berhubungan dari titik asal kepada titik pemakai untuk tujuan yang sesuai dengan kebutuhan pelanggan [1]

Pada dasarnya Sistem Logistik terdiri dari empat bidang dasar yaitu Logistik, Pemasaran, Produksi dan Keuangan. Adapun tujuan logistik yaitu :

a. Mengantarkan barang dan jasa pada tempat yang tepat

b. Mengantarkan barang dan jasa dengan waktu yang sesuai dengan kondisi yang diinginkan untuk memberikan nilai maksimal bagi Perusahaan

c. Bertanggung jawab untuk memastikan bahwa suatu produk yang tepat berada di tempat yang tepat, pada waktu yang tepat dan dengan harga yang tepat

\subsubsection{Entity Relationship Diagram}

Entity Relationship Diagram (ERD) adalah suatu model jaringan (network) yang menggunakan susunan data yang disimpan dalam sistem secara abstrak. Tujuan utama dari penggambaran ERD adalah untuk menunjukkan struktur objek data (entity) dan hubungan (relationship) yang ada pada objek tersebut. ERD berguna bagi professional sistem, karena ERD memperlihatkan hubungan antara data store pada DFD. [3]

\subsubsection{Unified Modelling Language (UML)}

Unified Modelling Language adalah bahasa standar yang digunakan untuk menjelaskan dan memvisualisasikan artifak dari proses analisis dan desain berorientasi obyek. [4]

Diagram UseCase atau UseCase diagram menyajikan interaksi antara UseCase dan aktor. Dimana, aktor dapat berupa orang, peralatan, atau sistem lainyang berinteraksi dengan sistem yang sedang dibangun. UseCase menggambarkan fungsional sistem atau persyaratan-persyaratan yang harus 
dipenuhi sistem dari pandangan pemakai. Diagram sekuensial atau sequence diagram digunakan untuk menunjukkan aliran fungsionalitas dalam UseCase. [7]

\subsubsection{UseCase}

Diagram UseCase atau UseCase diagram menyajikan interaksi antara UseCase dan aktor. Dimana, aktor dapat berupa orang, peralatan, atau sistem lain yang berinteraksi dengan sistem yang sedang dibangun. UseCase menggambarkan fungsionalitas sistem atau persyaratan-persyaratan yang harus dipenuhi sistem dari pandangan pemakai. [7]

\subsubsection{Class Diagram}

Class diagram menunjukkan kemampuan statis dari sebuah sistem dan tidak menunjukkan adanya aktivitas proses tertentu. Sebuah diagram kelas juga menunjukkan sifat hubungan antara kelas. Sebuah class diagram dapat menunjukkan hanya nama kelas, nama kelas dan atribut, atau nama kelas, atribut, dan method yang dipakai dalam kelas tersebut [5]

\subsection{Proses Bisnis Sistem}

Sistem ini berfokus pada proses transaksi penerimaan, pengiriman, dan permintaan barang bantuan logistik namun agar posko dapat melakukan transaksi perlu beberapa hal yang harus dipenuhi. Pertama user dengan hak akses Superadmin harus menginput data barang bantuan logistik, data posko bantuan, data posko pengungsi, data user posko ke dalam sistem. Admin Posko Bantuan adalah user yang memiliki hak akses dalam melakukan penerimaan dan pengiriman barang bantuan yang terdapat pada posko bantuan. Sedangkan Admin Posko Pengungsi adalah user yang memiliki hak akses dalam melakukan permintaan barang bantuan kepada posko bantuan. Penjelasan alur penerimaan, pengiriman, dan permintaan barang bantuan logistic dapat dilihat pada gambar 1.

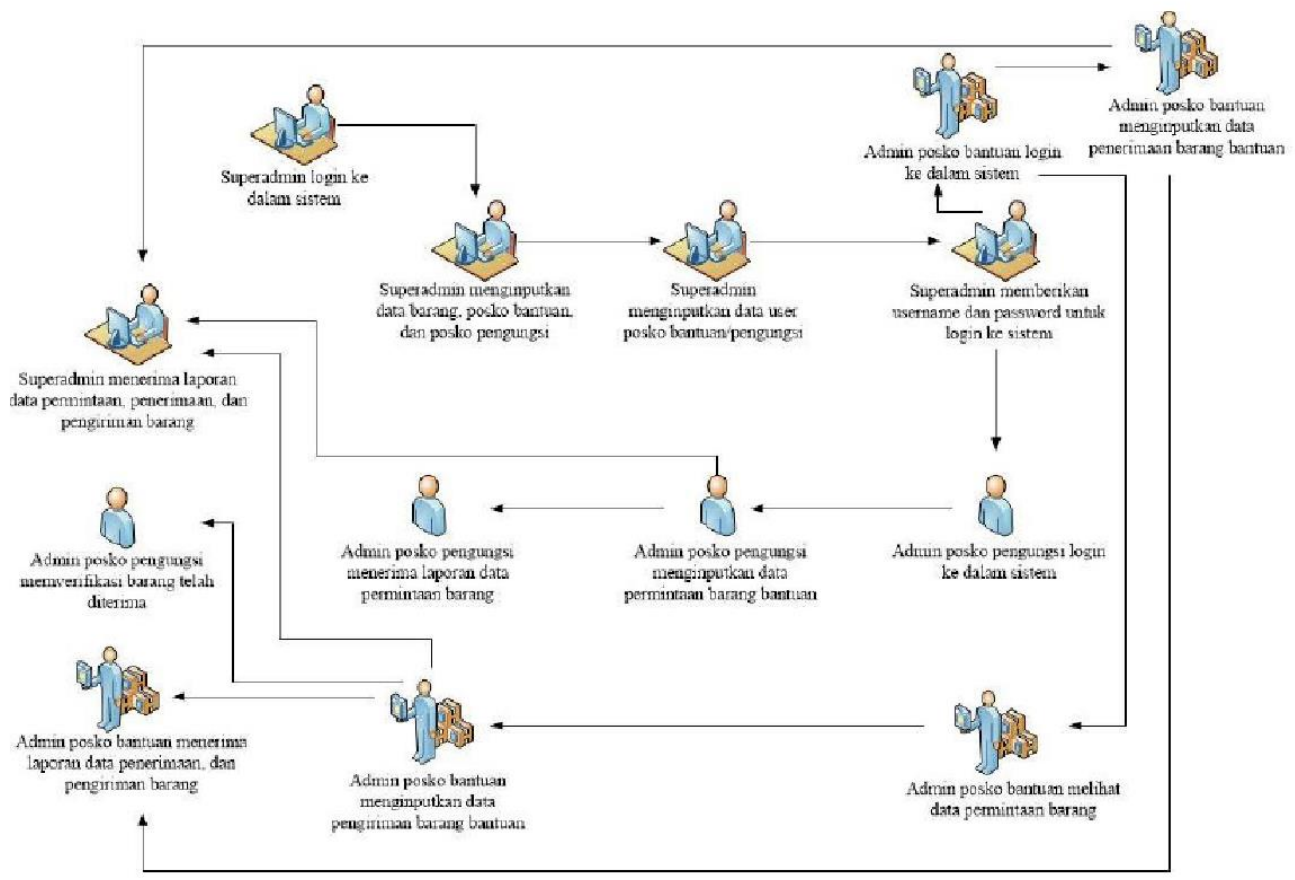

Gambar 1 Proses Bisnis Sistem warehouse bencana alam

\subsection{SRS (Software Requirement Specification)}


Kebutuhan fungsional yang ada pada Sistem Warehouse Bantuan Logistik Korban Bencana Alam (Studi Kasus : Gunung Merapi) dapat dilihat pada fungsional SRS ( System Requirement Spesification ) sebagai berikut :

\subsubsection{SRS Fungsional}

Kebutuhan fungsional merupakan kebutuhan-kebutuhan yang berhubungan dengan proses bisnis dari sistem yang dibuat. Dari analisis yang dilakukan, kebutuhan fungsional dalam sistem yang dibuat, berikut adalah daftar kebutuhan fungsional sistem

a. Sistem dapat mengelola data user posko bantuan dilakukan oleh Superadmin

b. Sistem dapat mengelola data user posko pengungsi dilakukan oleh Superadmin

c. Sistem dapat mengelola data barang dilakukan oleh Superadmin

d. Sistem dapat mengelola data posko bantuan dilakukan oleh Superadmin

e. Sistem dapat mengelola data posko pengungsi dilakukan oleh Superadmin

f. Sistem dapat memberikan laporan data pengiriman dilakukan oleh Superadmin, Admin posko bantuan

g. Sistem dapat memberikan laporan data penerimaan dilakukan oleh Superadmin, Admin posko bantuan

h. Sistem dapat memberikan laporan data permintaan dilakukan oleh Superadmin, Admin posko bantuan

i. Sistem dapat memberikan laporan data stok barangdilakukan oleh Superadmin, Admin posko bantuan

j. Sistem dapat mengelola data penerimaan dilakukan oleh Admin posko bantuan

k. Sistem dapat mengelola data pengiriman dilakukan oleh Admin posko bantuan

1. Sistem dapat melihat data posko pengungsi dilakukan oleh Admin posko bantuan, Admin posko pengungsi

m. Sistem dapat melihat data posko bantuan dilakukan oleh Admin posko bantuan, Admin posko pengungsi

n. Sistem dapat melihat data permintan dilakukan oleh Admin posko bantuan

o. Sistem dapat mengelola data permintaan dilakukan oleh Admin posko pengungsi

p. Sistem dapat melihat data pengirimandilakukan oleh Admin posko pengungsi

q. Sistem dapat melakukan verifikasi barang diterima dilakukan oleh Admin posko pengungsi

r. Sistem dapat mengelola data pesan dilakukan oleh Admin posko bantuan, Superadmin

Pada kebutuhan fungsional yang telah dipaparkan di atas, aktor yang terlibat dalam sistem ini adalah :

a. Superadmin

Superadmin adalah kepala atau pegawai dari dinas badan penanggulangan bencana alam yang bertugas untuk mengelola dan mengawasi bantuan logistik yang terdapat pada posko-posko ketika terjadi bencana alam.

Superadmin dapat mengelola data user, user posko bantuan, user posko pengungsi, barang, posko pengungsi, posko bantuan dan laporan-laporan transaksi yang terdapat dalam sistem tersebut.

b. Admin Posko Bantuan

Admin posko bantuan adalah pegawai/karyawan/relawan yang berada di posko bantuan yang bertugas untuk melakukan pengelolaan atau manajemen penerimaan bahan logistik, pengiriman bahan logitik, dan laporan penerimaan serta pengiriman bahan logistik terhadap posko pengungsi.

c. Admin Posko Pengungsi

Admin posko pengungsi adalah pegawai/karyawan/relawan yang berada di posko pengungsi yang bertugas untuk melakukan pengelolaan permintaan barang/bahan logistik serta memvalidasi barang yang telah diterima.

\subsubsection{SRS Non Fungsional}


Kebutuhan non fungsional merupakan kebutuhan-kebutuhan yang berhubungan dengan interaksi antar user dengan sistem yang dibuat. Dari analisa yang dilakukan, kebutuhan non fungsional dalam sistem yang dibuat, seperti pada daftar berikut :

a. Menggunakan login untuk masuk ke sistem

b. Sistem dapat mengelola profile user yang meliputi lihat profile, update profile, dan ganti password.

\subsection{Perancangan Sistem}

Perancangan sistem terdiri dari Usecase Diagram, Sequensial, Class Diagram Entity Relationship Diagram

\subsubsection{UseCase Diagram}

Diagram UseCase menggambarkan fungsi-fungsi yang terdapat pada sistem serta peran dan hak akses dari aktor pada Sistem Warehouse Bantuan Logistik Korban Bencana Alam (Studi Kasus : Gunung Merapi) yaitu Superadmin, Admin Posko Bantuan, dan Admin Posko Pengungsi. UseCase Diagram dapat dilihat pada gambar 2 berikut : 


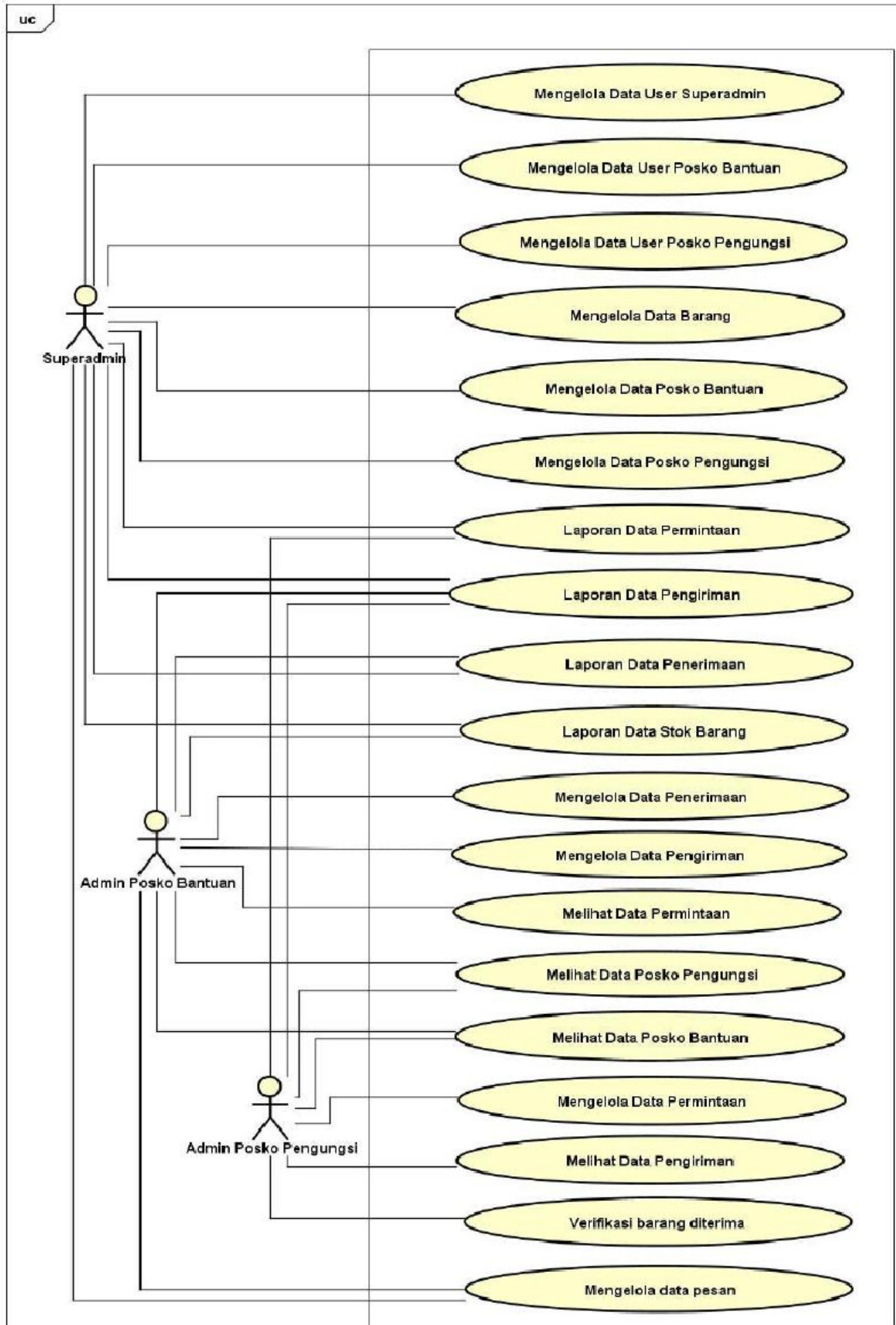

Gambar 2 Use Case Sistem warehouse bencana alam 


\subsubsection{ERD (Entity Relationship Diagram)}

Entitas Relationship Diagram dari Sistem Warehouse Bantuan Logistik Korban Bencana Alam (Studi Kasus : Gunung Merapi) dapat dilihat pada gambar 3 berikut :

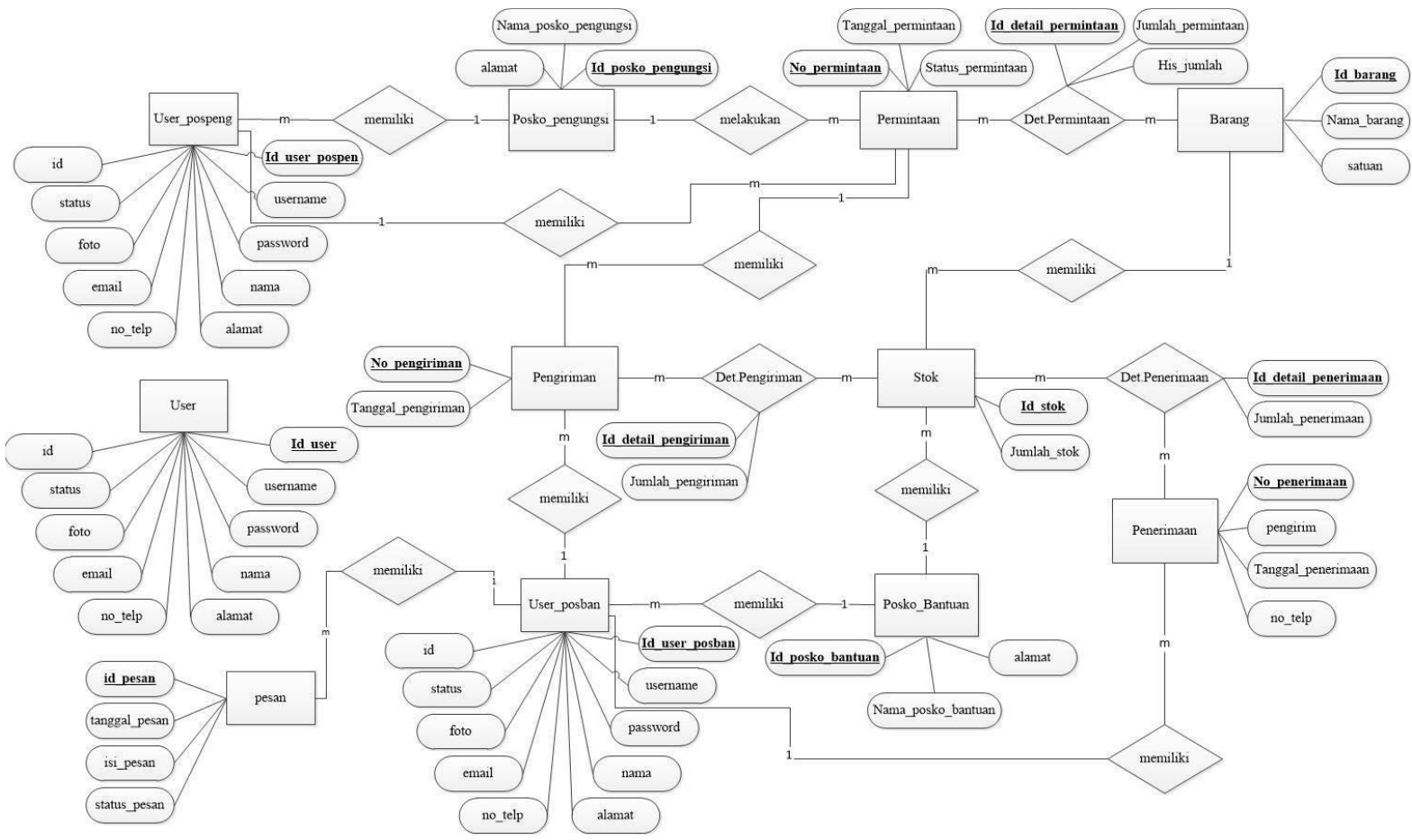

Gambar 3 ERD Sistem warehouse bencana alam

\subsubsection{Class Diagram}

Class diagram dari Sistem Warehouse Bantuan Logistik Korban Bencana Alam (Studi Kasus : Gunung Merapi) dapat dilihat pada gambar 4 berikut : 


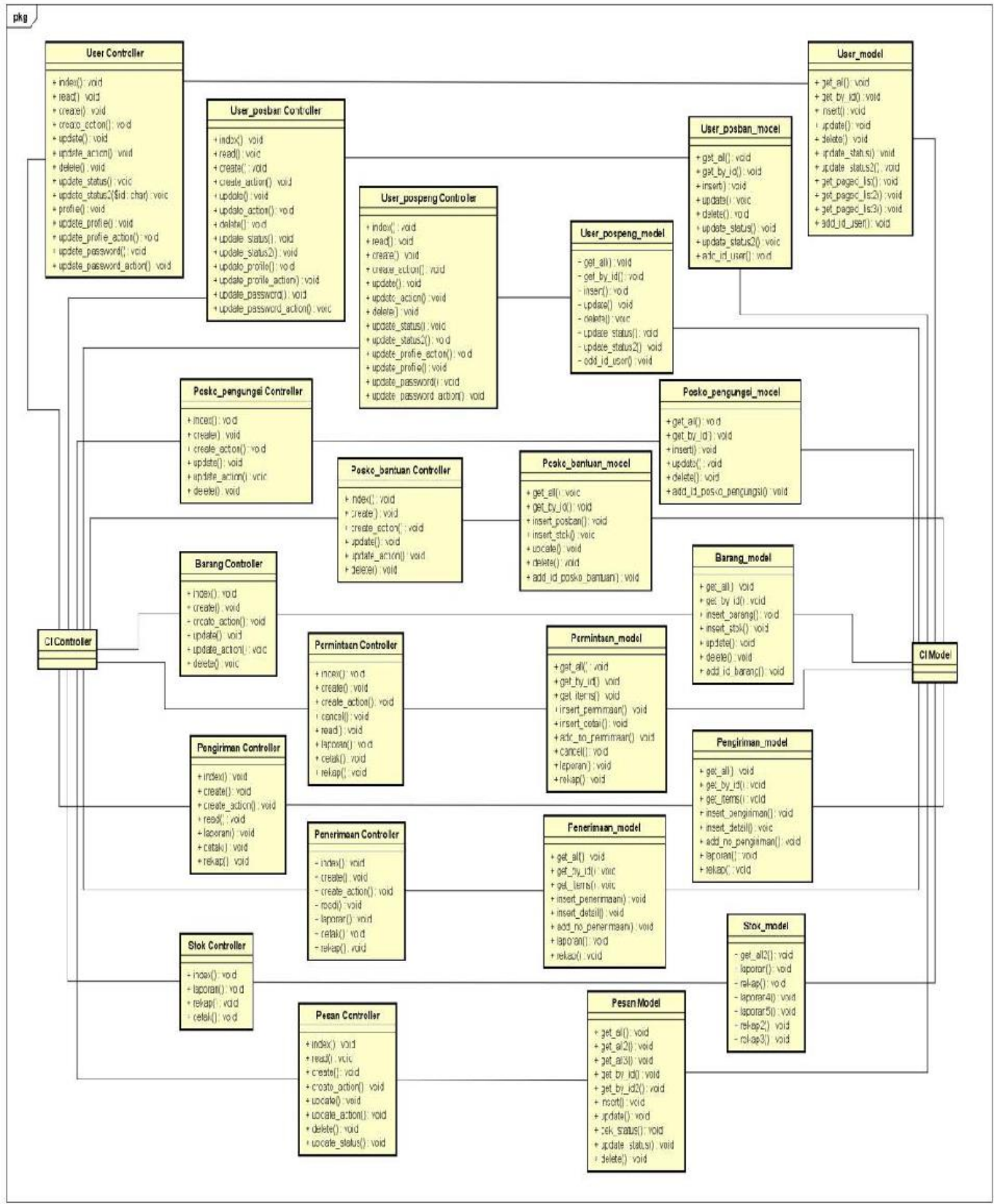

Gambar 4 Class diagram sistem warehouse bencana alam

\subsection{Pengujian}

Pengujian sistem dilakukan dengan metode black box testing yaitu pengujian yang hanya dilakikan dari segi spesifikasi fungsional tanpa menguji desain kode program. Berikut ini adalah pengujian pada Sistem Warehouse Bantuan Logistik Korban Bencana Alam Berbasis Web dengan Framework Codeigniter 3.0 (Studi Kasus : Gunung Merapi).

\subsubsection{Modul Superadmin}


Pengujian modul superadmin menunjukkan hasil pengujian terhadap fungsifungsi yang ada di dalam hak akses superadmin. Adapun hasilnya dapat dilihat pada tabel 1 :

Tabel 1 Tabel Pengujian Modul Superadmin

\begin{tabular}{|c|c|c|c|c|}
\hline No & Deskripsi & $\begin{array}{l}\text { Skenario } \\
\text { Pengujian }\end{array}$ & $\begin{array}{l}\text { Hasil Yang } \\
\text { Diharapkan }\end{array}$ & Kesimpulan \\
\hline 1 & $\begin{array}{l}\text { Pengujian menampilkan, } \\
\text { menginputkan, mengupdate, } \\
\text { menghapus, detail, } \\
\text { ubahstatus data user } \\
\text { superadmin }\end{array}$ & $\begin{array}{l}\text { Memilih menu } \\
\text { tindakan salah satu data } \\
\text { user superadmin }\end{array}$ & $\begin{array}{l}\text { Sistem menampilkan } \\
\text { cetakan atau perubahan } \\
\text { sesuia pilihan pada data } \\
\text { user superadmin. }\end{array}$ & $\begin{array}{l}{[\sqrt{ }] \text { Valid }} \\
{[] \text { Tidak valid }}\end{array}$ \\
\hline 2 & $\begin{array}{l}\text { Pengujian menampilkan } \\
\text { menginputkan, mengupdate, } \\
\text { menghapus, detail, } \\
\text { ubahstatus data admin } \\
\text { posko bantuan }\end{array}$ & $\begin{array}{l}\text { Memilih menu } \\
\text { data tindakan dari salah } \\
\text { satu untuk admin } \\
\text { posko bantuan }\end{array}$ & $\begin{array}{l}\text { Sistem menampilkan } \\
\text { data atau perubahan } \\
\text { admin posko bantuan }\end{array}$ & $\begin{array}{l}{[\sqrt{ }] \text { Valid }} \\
{[] \text { Tidak valid }}\end{array}$ \\
\hline 3 & $\begin{array}{l}\text { Pengujian menampilkan } \\
\text { menginputkan, mengupdate, } \\
\text { menghapus, detail, } \\
\text { ubahstatus data admin } \\
\text { posko pengungsi }\end{array}$ & $\begin{array}{l}\text { Memilih menu } \\
\text { data tindakan dari salah } \\
\text { satu untuk admin } \\
\text { posko pengungsi }\end{array}$ & $\begin{array}{l}\text { Sistem menampilkan } \\
\text { data atau perubahan } \\
\text { admin posko pengungsi }\end{array}$ & $\begin{array}{l}{[\sqrt{ }] \text { Valid }} \\
\text { [ ] Tidak valid }\end{array}$ \\
\hline 4 & $\begin{array}{l}\text { Pengujian menampilkan, } \\
\text { menginputkan, mengupdate, } \\
\text { menghapus, detail data } \\
\text { barang dan stok barang }\end{array}$ & $\begin{array}{l}\text { Memilih salah satu } \\
\text { menu tindakan data } \\
\text { barang dan stok barang }\end{array}$ & $\begin{array}{l}\text { Sistem menampilkan } \\
\text { data atau perubahan data } \\
\text { barang dan stok barang }\end{array}$ & $\begin{array}{l}{[\sqrt{ }] \text { Valid }} \\
{[] \text { Tidak valid }}\end{array}$ \\
\hline 5 & $\begin{array}{l}\text { Pengujian menampilkan, } \\
\text { menginputkan, mengupdate, } \\
\text { menghapus, detail data } \\
\text { posko bantuan dan posko } \\
\text { pengungsi }\end{array}$ & $\begin{array}{l}\text { Memilih salah satu } \\
\text { menu tindakan data } \\
\text { posko bantuan dan } \\
\text { posko pengungsi }\end{array}$ & $\begin{array}{l}\text { Sistem menampilkan } \\
\text { data atau perubahan data } \\
\text { posko bantuan dan } \\
\text { pengungsi }\end{array}$ & $\begin{array}{l}{[\sqrt{ }] \text { Valid }} \\
{[] \text { Tidak valid }}\end{array}$ \\
\hline 6 & $\begin{array}{l}\text { Pengujian menampilkan dan } \\
\text { mencetak laporan data } \\
\text { permintaan, pengiriman dan } \\
\text { penerimaan }\end{array}$ & $\begin{array}{l}\text { Memilih data } \\
\text { Laporan permintaan, } \\
\text { pengiriman dan } \\
\text { penerimaan }\end{array}$ & $\begin{array}{l}\text { Sistem akan } \\
\text { menampilkan list } \\
\text { laporan permintaan, } \\
\text { pengiriman dan } \\
\text { penerimaan barang } \\
\text { sesuai kriteria } \\
\end{array}$ & $\begin{array}{l}{[\sqrt{ }] \text { Valid }} \\
{[] \text { Tidak valid }}\end{array}$ \\
\hline
\end{tabular}

\subsubsection{Modul Admin Posko Bantuan}

Pengujian modul admin posko bantuan menunjukkan hasil pengujian terhadap fungsi-fungsi yang ada di dalam hak akses admin posko bantuan. Adapun hasilnya dapat dilihat pada tabel 2 :

Tabel 2 Tabel Pengujian Modul Admin Posko Bantuan

\begin{tabular}{|l|l|l|l|l|}
\hline No & Deskripsi & $\begin{array}{l}\text { Skenario } \\
\text { Pengujian }\end{array}$ & $\begin{array}{l}\text { Hasil Yang } \\
\text { Diharapkan }\end{array}$ & Kesimpulan \\
\hline $\mathbf{1}$ & $\begin{array}{l}\text { Pengujian menampilkan } \\
\text { data posko bantuan dan } \\
\text { posko pengungsi }\end{array}$ & $\begin{array}{l}\text { Memilih menu } \\
\text { data posko bantuan posko } \\
\text { pengungsi }\end{array}$ & $\begin{array}{l}\text { Sistem menampilkan } \\
\text { list data posko } \\
\text { bantuan posko }\end{array}$ & $\begin{array}{l}{[\sqrt{ }] \text { Valid }} \\
{[] \text { Tidak }} \\
\text { valid }\end{array}$ \\
\hline
\end{tabular}




\begin{tabular}{|c|c|c|c|c|}
\hline & & & pengungsi & \\
\hline 2 & $\begin{array}{l}\text { Pengujian menampilkan, } \\
\text { menginputkan, } \\
\text { mengupdate, } \\
\text { menghapus, detail data } \\
\text { stok, pengiriman dan } \\
\text { Penerimaan barang }\end{array}$ & $\begin{array}{l}\text { Memilih menu sesuai } \\
\text { pilihan data stok, } \\
\text { pengiriman dan } \\
\text { penerimaan barang }\end{array}$ & $\begin{array}{l}\text { Sistem menampilkan } \\
\text { data atau perubahan } \\
\text { stok, pengiriman dan } \\
\text { penerimaan } \\
\text { barang }\end{array}$ & $\begin{array}{l}{[\sqrt{ }] \text { Valid }} \\
{[] \text { Tidak }} \\
\text { valid }\end{array}$ \\
\hline 3 & $\begin{array}{l}\text { Pengujian menampilkan } \\
\text { jumlah posko pengungsi } \\
\text { yang melakukan } \\
\text { permintaan barang }\end{array}$ & $\begin{array}{l}\text { Memilih notifikasi pada } \\
\text { top navigasi disisi kanan } \\
\text { layar }\end{array}$ & $\begin{array}{l}\text { Sistem menampilkan } \\
\text { jumlah posko } \\
\text { pengungsi yang } \\
\text { melakukan permintaan }\end{array}$ & $\begin{array}{l}{[\sqrt{ }] \text { Valid }} \\
{[] \text { Tidak }} \\
\text { valid }\end{array}$ \\
\hline 4 & $\begin{array}{l}\text { Pengujian menampilkan, } \\
\text { menginputkan, } \\
\text { mengupdate, } \\
\text { menghapus, detail data } \\
\text { pesan }\end{array}$ & $\begin{array}{l}\text { Memilih create } \\
\text { pada list data } \\
\text { pesan dan menampilkan, } \\
\text { menginputkan, } \\
\text { mengupdate, menghapus, } \\
\text { detail } \\
\text { data pada form }\end{array}$ & $\begin{array}{l}\text { Apabila user memilih } \\
\text { Salah satu pilihan data } \\
\text { pesan, maka sistem } \\
\text { akan } \\
\text { mencetak atau } \\
\text { mengubah data } \\
\text { pesan ke database }\end{array}$ & $\begin{array}{l}{[\sqrt{ }] \text { Valid }} \\
{[] \text { Tidak }} \\
\text { valid }\end{array}$ \\
\hline
\end{tabular}

\subsubsection{Modul Admin Posko Pengungsi}

Pengujian modul admin posko pengungsi menunjukkan hasil pengujian terhadap fungsi-fungsi yang ada di dalam hak akses admin posko pengungsi. Adapun hasilnya dapat dilihat pada tabel 3 berikut :

Tabel 3 Tabel Pengujian Modul Admin Posko Pengungsi

\begin{tabular}{|c|c|c|c|c|}
\hline No & Deskripsi & $\begin{array}{l}\text { Skenario } \\
\text { Pengujian }\end{array}$ & $\begin{array}{l}\text { Hasil Yang } \\
\text { Diharapkan }\end{array}$ & Kesimpulan \\
\hline 1 & $\begin{array}{l}\text { Pengujian menampilkan } \\
\text { data posko bantuan dan posko } \\
\text { pengungsi }\end{array}$ & $\begin{array}{l}\text { Memilih menu } \\
\text { data posko bantuan } \\
\text { dan posko } \\
\text { pengungsi }\end{array}$ & $\begin{array}{l}\text { Sistem menampilkan } \\
\text { list data posko } \\
\text { bantuan dan posko } \\
\text { pengungsi }\end{array}$ & $\begin{array}{l}{[\sqrt{ }] \text { Valid }} \\
\text { [ ] Tidak valid }\end{array}$ \\
\hline 2 & $\begin{array}{l}\text { Pengujian Menampilkan, } \\
\text { menginputkan, mengupdate, } \\
\text { menghapus, detail data } \\
\text { permintaan } \\
\text { barang }\end{array}$ & $\begin{array}{l}\text { Memilih salah satu } \\
\text { menu data } \\
\text { permintaan }\end{array}$ & $\begin{array}{l}\text { Sistem menampilkan } \\
\text { data atau perubahan } \\
\text { pada permintaan } \\
\text { barang }\end{array}$ & $\begin{array}{l}{[\sqrt{ }] \text { Valid }} \\
\text { [ ] Tidak valid }\end{array}$ \\
\hline 3 & $\begin{array}{l}\text { Pengujian menampilkan dan } \\
\text { mem-verifikasi } \\
\text { Data pengiriman } \\
\text { barang ke posko pengungsi }\end{array}$ & $\begin{array}{l}\text { Memilih menu } \\
\text { data verifikasi } \\
\text { barang diterima }\end{array}$ & $\begin{array}{l}\text { Sistem menampilkan } \\
\text { list data dan } \\
\text { verifikasi } \\
\text { pengiriman } \\
\text { barang ke posko } \\
\text { pengungsi }\end{array}$ & $\begin{array}{l}{[\sqrt{ }] \text { Valid }} \\
\text { [ ] Tidak valid }\end{array}$ \\
\hline 4 & $\begin{array}{l}\text { Pengujian } \\
\text { menampilkan } \\
\text { laporan data } \\
\text { permintaan }\end{array}$ & $\begin{array}{l}\text { Memilih data } \\
\text { Laporan } \\
\text { permintaan }\end{array}$ & $\begin{array}{l}\text { Sistem akan } \\
\text { menampilkan list } \\
\text { laporan permintaan } \\
\text { barang sesuai } \\
\text { kriteria }\end{array}$ & $\begin{array}{l}{[\sqrt{ }] \text { Valid }} \\
\text { [ ] Tidak valid }\end{array}$ \\
\hline
\end{tabular}




\begin{tabular}{|l|l|l|l|l|}
\hline $\mathbf{5}$ & $\begin{array}{l}\text { Pengujian menampilkan } \\
\text { jumlah posko } \\
\text { bantuan yang melakukan } \\
\text { pengiriman barang } \\
\text { terhadap posko pengungsi }\end{array}$ & $\begin{array}{l}\text { Memilih notifikasi } \\
\text { pada top navigasi } \\
\text { disisi kanan layar }\end{array}$ & $\begin{array}{l}\text { Sistem menampilkan } \\
\text { jumlah posko } \\
\text { bantuan yang } \\
\text { melakukan } \\
\text { pengiriman barang } \\
\text { terhadap posko } \\
\text { pengungsi }\end{array}$ & $\begin{array}{l}\text { [ ] Tidak valid } \\
\end{array}$ \\
& & & \\
\hline
\end{tabular}

\section{KESIMPULAN}

Kesimpulan yang dapat diambil dari penelitianperancangan sistem warehouse bantuan logistik korban bencana alam (studi kasus : gunung merapi) adalah sebagai berikut :

a. Data yang dikelola dari sistem meliputi data barang, data user baik superadmin, admin posko bantuan, maupun admin posko pengungsi, data posko bantuan, data posko pengungsi, data penerimaan, data pengiriman, dan data permintaan barang.

b. Dari hasil pengujian dengan metode black box sistem diperoleh modul-modul untuk superadmin, admin posko pengungsi dan posko bantuan yang semua fungsionalitasnya valid.

c. Modul-modul dari sistem dalam sistem ini yang sudah melewati pengujian adalah diantaranya pengolahan data barang, datauser, data posko, data penerimaan, data pengiriman, data permintaan, pembuatan laporan, dan perhitungan jumlah stok barang

\section{DAFTAR PUSTAKA}

[1] Ballou, R. H. , 1992, Business Logistics Management, 4th ed., Prentice-Hall, Inc. New Jersey.

[2] Bowersox, J. D. , 2002, Manajemen Logistik "Integrasi Sistem-sistem Manajemen Distribusi Fisik dan Manajemen Material”, Jakarta: Bumi Aksara.

[3] Fathansyah, I. , 2001, Basis Data, Bandung: Informatika. Hermawan, J. , 2004, ANALISA DESAIN \& Pemrograman Berorientasi Obyekdengan UML dan Visual Basic.NET, Yogyakarta : Andi.

[4] Hermawan, J. , 2004, ANALISA DESAIN \& Pemrograman Berorientasi Obyek dengan UML dan Visual Basic.NET, Yogyakarta : Andi.

[5] Kendall, K. E. , 2011, Systems Analysis and Design - 8th edition, Pearson Education, Inc.

[6] Lambert, D. M. , Stock , J. R. , 2001, Strategic Logistic Manajement, Fourth Edition, Mc Graw Hill, New York - USA.

[7] Sholiq, 2006, Pemodelan Sistem Informasi Berorientasi Obyek dengan UML, Yogyakarta: Graha Ilmu. 